\title{
Work, training and social sensibilities: analysis from the experiences of fit-fluencers
}

\author{
Pedro Matías Lisdero ${ }^{1,2}$ (D) Jorge Luis Duperré ${ }^{(\mathbb{D}}$
}

Received: 31 May 2021 / Accepted: 6 July 2021 / Published online: 2 August 2021

(c) The Author(s), under exclusive licence to Springer Nature Switzerland AG 2021

\begin{abstract}
The article aims to reflect on the transformations that have taken place in the "world of work", based on their connections with the way in which subjects "train themselves". In the interstices between "work time" and "leisure/training time", some important characteristics of current body politics (the ways in which societies accept the distribution and use of bodies and their energies) become visible. Specifically, we explore here the emerging phenomenon of "fit-influencers", contemporary referents of the "virtual" scene (social networks) through the promotion of sports and eating routines. In this sense, our corpus of analysis has been constructed from an ethnographic work located in Argentina, from which narratives that these actors present in social networks (Virtual Ethnography), and in situations of in-depth interviews, are recovered. These narratives allow us to understand the social sensibilities associated with these practices, enabling us to link the emergence and expansion of fit-influencers with a process of renewal of the "spirit of capitalism" (sensu Weber), which would translate into an updating of the "political economy of morality" (Scribano in ¡Disfrútalo! Una aproximación a la economía política de la moral desde el consumo, Elalephcom, Ciudad Autónoma de Buenos Aires, 2015). To be clearer, "political economy of morality" refers to a series of mechanisms of social domination and exploitation of bodily energies, which are legitimised as moral principles associated with enjoyment through consumption. The final reflections we present are oriented towards thinking about how the new "digital gurus" of routines and "homemade" prescriptions become guarantors of the organisation of work, by establishing parameters for the management of bodies and emotions that are associated to a "renewed" order of accumulation.
\end{abstract}

Pedro Matías Lisdero

pedrolisdero@gmail.com

Jorge Luis Duperré

jlduperre@gmail.com

1 National Scientific and Technical Research Council (CIECS - CONICET Y UNC), National University of Villa María (IAPCS), Córdoba, Argentina

2 University of Palermo (CICSEC), Buenos Aires, Argentina 
Keywords Digital labour $\cdot$ Sensibilities $\cdot$ Bodies $\cdot$ Emotions $\cdot$ Fitfluencer

\section{Introduction}

The paper aims to reflect on the transformations that have taken place in the "world of work", based on their connections with the way in which subjects "train themselves". In the interstices between "work time" and "leisure/training" time, some important characteristics of social structuration processes (Giddens 2003) become visible. We are particularly interested in the impact that the transformations of work experiences, expressed on some specific narratives, have on the constitution of the current body politics (Scribano 2017). To account for this, we decided to focus on fit-influencers as an emerging phenomenon: these are contemporary referents of sporting and eating routines, who acquire this status through their participation in the virtual scene (social networks).

In this sense, our corpus of analysis has been constructed from an ethnographic work located in Argentina, from which narratives that these actors present in social networks (Virtual Ethnography), and in situations of in-depth interviews, are recovered. These narratives allow us to understand the social sensibilities associated with these practices, enabling us to link the emergence and expansion of fit-influencers with a process of renewal of the "spirit of capitalism" (sensu Weber), which would translate into an updating of the "political economy of morality" (Scribano 2015). To be clearer, "political economy of morality" (PEM) refers to a series of mechanisms of social domination and exploitation of bodily energies, which are legitimised as moral principles associated with enjoyment through consumption. The final reflections we present are oriented towards thinking about how the new "digital gurus" of routines and "homemade" prescriptions become guarantors of the organisation of labour, by establishing parameters for the management of bodies and emotions that are updated to a "renewed" order of accumulation.

\section{Some starting points: training emotions through social networks in contexts metamorphosis of work}

To advance the objectives set out above, it is necessary to make some starting points explicit. We will group the arguments around two dimensions: first, we develop some contributions of a sociology of bodies/emotions to understand the transformations of labour in the context of the metamorphosis of global capitalism; and second, we contextualise a research practice situated around the experience of fit-influencers, thus contributing to its definition. At this point, we make explicit some theoretical connections that allow us to interpret the narratives of fit-influencers as an entry point to social sensibilities. 


\section{Contributions from a sociology of body/emotions: work in Societies 4.0}

Our concern is linked to the possibilities of identifying the sensibilities that are both cause and consequence of the framework that currently shapes the transformations in the "world of work" (Antunes 2005) and the expansion of new body training techniques (Melucci 1977). To be more precise, we are interested in reflecting on the cognitive-affective practices (Scribano 2017) involved in the experiences of subjects who participate in a dynamic labour market, performing certain "trained" skills. These are linked to the premises of "physical well-being" and "health", but also to certain expressive and identity demands. In this sense, we consider that the popularisation of certain disciplines, whose practice used to be reserved for small groups (among which we highlight Running, Crossfitm, Kitesurfing, Zumba, Pilates and Yoga), expresses a renewed interest in "the body", thus confirming the incipient process that Melucci had already noticed in the 1970s. In the face of the expansion of diverse practices, Melucci observes: "The body seems to become the secret place, to which only the individual holds the key, and to which he can return in search of a definition of himself that escapes rules and expectations (...)" (1977: p. 7).

However, this observation is not limited to the ideal of a "healthy body" that is promulgated, but also indicates the underlying identitary character. Working and training thus constitute "ways of life", which are linked to the social agents' sense of belonging to a collective, the strategies of "escape" from the work routine, the way in which they "connect" with their "inner world" and their environment, and so on. Indeed, contact with "the spiritual", with "oneself", with "nature", is associated with the capacity — mediated by a bodily technique (Mauss 1979)— to redefine relationships, which seem to constitute the conditions of emergence/expansion of these practices: "I train because I am stressed", "I work/live better because I am 'trained".

In consonance with this approach, it is necessary to underline the importance of the notion of the body, ${ }^{1}$ as a substratum where the social transformations that involve the processes of ongoing social restructuring (Giddens 2003) are "embodied" (such as the aforementioned processes of identity constitution, the meaning of work spaces/leisure-recreation spaces, the uses of time, and the very emergence of the body as a space of/in production). But the corporeal also refers us to the logics of consumption and control to which it is subjected.

\footnotetext{
1 From the perspective we hold here, we understand the body in the tension between its individual, subjective and social features: "The individual body is a phylogenetically elaborated construction that indicates the physio-social places and processes through which the naturalised perception of the environment connects with the subjective body. The subjective body is the self-perception of the individual as a space of perception of context and environment as a 'locus' of vital sensation rooted in the experience of an 'I' as the centre of gravitation of its practices. The social body consists of the embodied social structures that vectorise the individual and subjective body in relation to its connections in life-living-with-others and for-others" (Scribano 2017). In the complexity of this starting point, the idea of social "emotion" can then be understood as a sociological object that is configured beyond isolated individuals, but which at the same time is expressed in and by the interplay between perceptions, impressions and sensations that structure individuals. Bodies/emotions must be understood in a non-essentialist continuum as the locus of the structuring processes of "the social" (for more on this particular perspective on the sociology of the body/emotions see: Scribano 2017, 2018, 2021).
} 
As a result, the proliferation of actors approaching these training practices is associated with the emergence of a diversity of market players willing to commercialise a multiplicity of goods ranging from personal trainer services, through the sale of clothing, to the organisation of mass sporting events. The search for what is most "intimate" and "natural" in the body coexists with the demands of a society guided by instrumental rationality, which imposes an increasing manipulation of identity to ensure productive performance and mass consensus (Melucci 1977, p. 7). Thus, if we support the conception of identity as a field of struggle where structural antagonisms are embodied, we would be able to re-construct the history of capital as the constant conflict to re-invent the capacities of the body in order to convert them into capital, and the labour process as a particular moment where these metabolic mechanisms that regulate the activity of subjects are configured (Lisdero and Marengo 2010).

One dimension that allows us to understand more fully the relationship between body and identities is that of "bodily energies", as an object of appropriation, but also as a substratum that feeds the mechanisms of elaboration of these identities. One thing to note in this respect is that this notion cannot be defined on the basis of looking at the body as a "motor". Instead, it must be thought of as a process of construction that is always dynamic, and tied to the historically constituted mechanisms for metabolising them into social relations. We point this out because the approach to the energy-body relation does not usually escape the "physiological" bias that occludes the possibility of recognising the socio-historical relations that produce it. In this direction, and taking a critical look at the notion of energy in the "sciences of work", it is possible to observe that the concept of "utility" creeps into the definition of human capacities, and the possibility of "mercantile calculation" guides the reflections on the activity of the same. It is in this sense that, in the face of the model of the body as a human motor reduced to a physiological source of energy, it is necessary to oppose it with a political and social conception (to take Marx's example). In this way, the boundary between this body, the social and the individual, begins to be redefined in relation to the process of value creation and capitalist valorisation.

Our point of view, in turn, incorporates another fundamental category to complement the relationship between the body, logics of production and practices of consumption. We refer to the "political economy of morality" (PEM), in the terms formulated by Scribano (2015): "a set of practices of domination/exploitation that have become moral principles" (p. 10), which are expressed through the "practices of enjoyment" (that is: enjoyment as a result of the possession of objects, including the subjects that have become such entities). In this respect, the author states that:

PEM finds in enjoyment through consumption the occasion to actualise three of its most important operational/functional features: making practices become moral imperatives, producing the necessary mystification between laws of things and norms of men, and delineating the cognitive/affective contours implied by the acceptance of the universalisation of a particular interest. (p. 11)

Scribano characterises the first assumption, referring to the moral dimension, as emerging from a dialectic between "religion/belief" and the expansion of 
global capitalism. In other words, we are dealing with is a "neo-colonial" dogma (secular, desacralised religion), whose characteristics are: the enthronement of merchandise and profit (which establishes a "social regime of things") and the alienation of its devotees/consumers (now turned into objects of desire for the enjoyment of others). In this way, the author argues that it is possible to think of the forms that present sociability takes on as a set of dogmatic beliefs, moulded by the logics of the market, where things are invested with quasi-magical or phantasmagorical qualities (the "fetishism of the commodity", Marx would note). In short, it is these forms of sociability - which equate the subject of faith with the subject of consumption, and establish a regime of sensibility based on a religion that reproduces the mechanisms of exploitation-that Scribano calls PEM.

In this framework, we understand that the emergence of new body training techniques implies, above all, a particular disposition for "emotional training" that is inscribed in this PEM. From the actors' point of view, a new maxim seems to be reconstructed that we could synthesise in the expression "training emotions" as a way of "accommodating the body for work", in other words, of incorporating a series of cognitive and affective practices aimed at "enduring" labour tensions, "decompressing" conflicts, "making the daily experience of work tolerable" (Lisdero et al. 2017).

Another element that we need to highlight to complete our conceptual framework is the metamorphosis of work in the "4.0 Societies" (Scribano and Lisdero 2019). Such a designation has to do with the place occupied by the internet and "the digital" in the processes of interaction and socialisation with great predominance in the present. Thus, the play of proximities/distances that shape both interpersonal and mediated relations and work/training spaces is re-structured. But in addition, "the digital" is intimately linked to the "desire" and "consumption" that contour these work/social experiences (in line with the morality described in the previous paragraph). Thus, the spectacularisation of virtual training becomes a platform of "re-production" in itself, as it favours a temporal regime of the corporeally desirable in interactive dynamics. In this sense, if movement and speed is what imprints the rhythm of our daily lives, the metamorphoses of the labour market and its reticular forms in the societies of spectacularised consumption impregnate our bodies with the various subtle variants of the historical mandate of modernity: "time is money". As a new turn of the machinery linked to the expansion of this logic, the transformations of training seem to naturalise this "rhythm" as long as "business works".

In short, if work historically represented the way in which the valorisation and expropriation of the energies of bodies was configured and regulated, it is no less true that these mechanisms were accompanied by various forms of "conditioning" a body "made to measure" for productive processes. In continuity with this point, we can think of the current transformations in the way in which society "trains" its productive bodies - together with the centrality that identity configurations and the resulting affective regimes acquire in this scenario-as indicators of the renewal of a process that takes us back to the origins of capitalism. It is understood, then, that reflecting on the way in which workers feel in relation to these forms of trainingobserved through the emerging narratives of these actors-contributes to thinking 
about certain patterns of movement and inertia of bodies and, therefore, to understanding the logics of structuring our complex societies.

\section{The narratives of fit-influencers in a situated research context}

Since the expansion of social networks, individuals express themselves through their digital devices with the intention of generating visibility of their own lives. By externalising everything that would constitute their private and intimate lives (Rodríguez 2015), a certain hybridisation is generated between the online and offline worlds. All of this gives us the indication that we are going through a stage in which the senses converge with technology, in pursuit of new discoveries and authenticity, thus redefining the notion of perception through the digital gaze (Pinheiro Koury 2019).

If we recognise, as Habermas (2019) does, the communicative nature of every body/emotion, we can understand how the narrative dimension is not exhausted in the literalness of what is enunciated. From an analytical point of view (although starting from different premises from those we hold here), Alasuutari (1997) claims "narrative practices", from which it is possible to have genuine access to the everyday life of the actors, in the form of stories. In continuity with this approach, Gubrium and Holstein (2008) deal with "narrative ethnography", which they characterise as a way of...

... empirical inspection [focusing on] the social processes and circumstances through which narratives are constructed, promoted and resisted. We can see and hear how the people involved actively draw on or respond to the contexts, contingencies and resources to craft their narratives. In other words, we can witness how narrative control is exercised as social interaction and conflicting interests come into play. (p. 256)

Going back to the emotive character of the narration, far from a dispassionate chronicle, this type of plot recreates the events with which its author is linked from his subjectivity (Goldie 2003). But the affective is also evident in the non-verbal resources "in-corporated" by the narrator. In the case of in praesentia interaction, kinesic and proxemic features constitute markers from which we can infer the "mood" of the interlocutors. On the other hand, in the interaction in absentia (that is, mediated by digital devices) the performance of the body is inscribed in other spatio-temporal dynamics, accompanying other forms of expressivity that social networks make available to their users.

From what has been said so far, we can point out that the narrative analyst should not limit himself to the task of compiling and dissecting the text, but should also contemplate the analysis of the circumstantial and spontaneous "performance" of the narrator. At this point our analytical perspective acquires relevance, since the expressivity resulting from the body/emotion placed in a situation of (virtual) interaction constitutes our objets of observability. In other words, we propose to recover the narratives of "self" of the fit-influencers, from a strategy that puts in tension the echoes of the voices replicated in the on-line/offline spaces (from a methodological strategy that combines techniques directed to these spaces). 
Before going on to explain some characteristics of the methodological design, it is necessary to clarify that these transformations, which are the object of registration and reflection in our research, take place within the framework of a new stage of world capitalism. It expresses the basic relations of economic exploitation, cultural alienation and political domination (Van den Ecker and Sevignani 2020), despite its updated "spirit". In this sense, we can assert that the convergence between "industry 4.0" and the globalisation of digital consumption corroborates forms of exploitation through the restructuring of the politics of sensibilities (Scribano and Lisdero 2019), whose narratives are incessantly re-created in social networks.

If we refer to our research in this regard, as we progressed in the problematisation of the relationship between new training techniques and work, we observed the emergence of a social actor that has great relevance in this present scenario. We refer to influencers (a name that corroborates the centrality of their role) and, more specifically, to the segment of them who have gained popularity through the promotion of exercise routines and recipes oriented towards "healthy" eating. After this identification, we conducted a thorough literature review, from which we were able to confirm that, in the field of social sciences, there are a considerable number of studies that have attempted to delimit certain practices of influencers through digital platforms such as Facebook, Twitter and Instagram. Without claiming to be exhaustive in their enumeration, we recover the productions on the content of these actors and their link with misleading advertising (Gómez Nieto 2018); Instafama (Marwick 2015); the main instagrammers in Ecuador (González Carrión and Aguaded 2019); digital fashion influencers on Instagram (Gomes Coelho Gentil and Cipiniuk 2019); influencers' perceptions of the transparency of content they advertise in Chile (Guiñez-Cabrera et al. 2020); self-branding and the rise of influencers in digital media (Khamis et al. 2017); influencers and the reconfiguration of work in Singapore (Abidin 2016); influencers' personality on Instagram (Ramírez Villanueva 2018); the power of influence and the link with follower communities (Fernandez Lerma 2017); Spanish influencers' content on the Covid-19 pandemic (TorresRomay and García Mirón 2020); among others.

Regarding the productions that take sports influencers or fitness influencers as the focus of study, we can highlight some works on influencers and running in women (Hijós 2018); the promotional content of the Instagram accounts of two famous athletes (Simó Quiles 2018); wellness influencers, health and the fitness industry (Noonan 2018); among others.

Some characteristics of these actors are provided by Khamis et al. (2017), who point out that:

In contrast to traditional celebrities who have gained public recognition because of their professional talent, social media influencers (from now on called 'influencers'), have gained fame by successfully branding themselves as experts on social media platforms (Khamis et al. 2017, cited in Schouten et al. 2020, p. 2).

Although most of the images published show athletic bodies, the fit-influencers make it clear that what is important is not only what you see but what you feel: they 
maintain that "the key is to feel good about yourself". However, from the analysis of their publications, we can see that for the fit girls (most of them are women), aesthetics and admiration in the eyes of others are synonymous with success: a reward for the effort of the daily routine, and an incentive to continue. They argue that one should never stop moving, conform or stagnate in the "comfort zone" (routine behaviour to achieve a constant performance, without taking any risks). Thus, the images show bodies in movement, smiling faces and playful gestures. In short, "joyful bodies" (Cigaina and Pascual 2020). "Training is synonymous not only with well-being, but also with happiness, especially when the desired results are obtained: the best version of oneself" (2002, p. 7), the authors add. For his part, Hijós points out that:

In a boom for the shift towards a 'healthier lifestyle', the need to transform the body is often being promoted on social media by 'fitness gurus' and professional athletes, but also by 'regular people' chosen by brands. These 'fit-influencers' present themselves as "friends" who impart advice on how to follow a lifestyle that revolves around fitness, inciting the consumption of certain products and activities, while reinforcing trends based on hegemonic stereotypes of the modern, attractive body. (2018, p. 54)

In the context of the research we have been developing since 2016 in the city of Villa María (Province of Córdoba, Argentina), our approach consisted of a qualitative-quantitative strategy, which included: a. virtual ethnography and in-depth interviews; b. the development of a database on gyms and sports/recreational spaces; and c. a survey of managers of these gyms. Although it is not possible to elaborate extensively on the details of these techniques, we are interested here in a brief reconstruction of some of the decisions taken in the first point.

In a first stage, we turned to nine key informants, selected for their immersion as local "experts" or "managers" of the practices we were interested in (fitness, running, yoga, etc.). Then, we conducted in-depth interviews with workers involved in the same practices, contacting them through the "snowball" technique, and completing the sample once we observed theoretical saturation criteria. At the same time, we developed a Virtual Ethnography strategy (De Sena and Lisdero 2014) from which interactions were recorded from two social networks: Facebook and Instagram. This was complemented with the exploration of journalistic articles in local and national media where the voices of the fit-influencer were defined and given space for expression.

Although we do not want to spend too much time on the characterisation of the local context in which this research is taking place, we can mention that the data constructed from the aforementioned research techniques refer us to the expansion of the "world of training" in an intermediate Argentinean city. Thus, the elaboration of a "database on gyms" allowed us to identify 99 training spaces that have emerged mainly in the last 10 years. Even if we take into account that according to estimates made by the Villa María Statistical Centre, the city has 87,563 inhabitants in 2019, with an Economically Active Population (EAP) of 49.12\%, that is, around 43 thousand people, of which 40 thousand are employed (Villa María Statistical Centre-Labour Market 2019), the inference we make regarding the number of people who attend gyms is almost $13 \%$ of the city's working population. We must keep 
in mind that the practice of what we call here new body training techniques exceeds these training spaces, which gives us an image of a city traversed by the mandate to "train".

Returning to the initial problem, our interest focused on how to record the emergence of fit-influencers in the scenario we have just described. Based on a process of immersion in social networks, we identified a series of profiles that concentrated interactions around these techniques, creating two recording tools: a database oriented towards characterising profiles, and a map of relationships that seeks to synthesise the map of usual exchanges on the network. This made it possible to select the central actors in the interaction networks. From this instrument, we began to record content and interactions linked to four narrative axes (associated with our research): (1) training and training biographies (how the actors define their activities, their bodies, emotions, evaluations, and how they feel about training); (2) references to the field of work; (3) specificity of the digital medium; and (4) health: spirituality, health/balance, body/health, food and eating practices. We standardised processes for obtaining information through the networks, and made progress in the use of a field diary containing the record.

As a complement to the virtual ethnography strategy, and taking up some contributions from the field of visual studies (Scribano and Lisdero 2019), we deployed an ethnographic observation strategy in a running group and in a gymnasium. The observation guide recovered the general guidelines exposed for virtual ethnography, however, we also incorporated here a premise that has to do with the possibility of producing photographic-images in the fieldwork (stressing the records of images obtained from social networks). The field diary obtained from this work contains the researchers' annotations and an accumulation of images produced in diverse practices that tension the "online/offline". The in-depth interviews enabled us to identify narratives associated with the emotional ones around the new body training techniques and to describe the identity processes linked to the subjects' work experiences.

Taking into account a general view, we were able to identify local actors and collect their testimonies, thus managing to strain the data extracted from the literature on the subject. The recording of national and foreign newspapers and media on fitinfluencers allowed us to reflect on the local-global logics that reveal the ways of behaving on and through the Internet (marketing strategies and dynamics of consumption, exhibitable/hidden bodies, affective norms, impact in terms of followers, etc.). Despite the relativisation of the origin of the actors who participate in virtual environments, it is necessary to clarify that the incorporation of those who do not live in the city is duly justified, taking into account the differences in the interactive volume, the scope of the publications, the sponsorship or not of the latter, etc. Nor did we consider the particularities of local fit-influencers as a whole in relation to nationally recognised profiles: We will only clarify in this sense that although the quantitative differences in terms of audiences are notorious, and even in terms of the degree of monetarisation of the activities (as well as the self-perception of the activity), despite all these differences we have focused on those dimensions of the local profiles where the content on "training" guide a specific practice from the 
networks, the common components of which we will develop in greater detail in the next section.

\section{Training: a requirement to "be well”}

If we summarise an overview from the testimonies and "publications", of "famous" fitinfluencer's we find a set of characteristics that could be summarised as follows:

- Almost all of them are women;

- They become referents "without intending to"; "spontaneously", by sharing their "experiences";

- They are called "motivators", "coaches", "fitness girls", "ambassadors" of this or that brand;

- The "followers", from the practice of "applying", consolidate the position of their influencer. They speak of a "fit family".

In the journalistic publications analysed, the notion of "entrepreneurs" who contribute to "setting trends" also emerges. Although the "swap" (exchange of non-conventional advertising for products) is a way of "valorising" the practice, some of the fitinfluencers manage to monetise it in different ways (also depending on the different platforms), all of which are oriented towards receiving income from "advertising" and "sponsorship" ("ambassadors"). It is notable, moreover, that some of the famous fit-influencers come from gastronomy, coaching, but also from journalism, business administration, etc.

To make our presentation more comprehensible, it is important to clarify in what terms we think of the articulation between work and emotional training in these practices. We begin by pointing out that our concern revolves around the experiences of actors in the world of fitness, inserted in various work activities (which may or may not have to do with "the world of exercise") whose practices are delineated by the premise of physical and emotional "well-being" (according to certain parameters of productivity):

I try to transmit that it is possible, that being well is something calm and not so strict, the same with sport: to show the enjoyment of physical activity [...] I think my followers identify with me because of that: normal people, who don't have all the time in the world to dedicate to health but who want to be better. Flor Fernández (in ELLE magazine, Clarín-28.08.2018)

\footnotetext{
${ }^{2}$ For the survey of the national digital media's coverage of the actors in question, we opted for a search based on keywords and explicit references linked to training, technological devices, social networks, work, etc. We also focused on the names of the country's most popular references. Once the material was collected, we organised it according to the media from which it was extracted and the date of publication. We then ranked the contents according to the relevance of the data provided by each article, in accordance with our theoretical categories.
} 
As can be seen, the impulse of the networks around the massification of the search for "being well" has a supposed "amplifying" content, that is, it is structured on the promise of "we can all be well". It is worth adding that the way in which the protagonists (the fit-influencers) experience these practices has its correlate on the expressive and identity level.

I focus not only on physical health but also on mental and emotional health. I really like to enjoy life and share with family and friends and I try to give people that motivation and not just focus on what they eat or how they exercise. Micaela Méndez (in ELLE magazine, Clarín-28.08.2018)

... I was very sedentary and didn't feel comfortable in my body, and at 23 I decided that I wanted to be fit. I was already healthy but I wanted to inhabit the best body I could get. Because I am in my body $24 \mathrm{~h}$ a day. Agustina D’Andraia (in ELLE magazine, Clarín-28.08.2018)

Thus, the narratives on training are framed in a search that overflows the timespaces of "exercise", "family" or "work". Instead, the body-together with digital mediation-is constituted in a "specific" space traversed by the coordinates of an identity demand:

... smartphones started to be used, Instagram appeared and I started to follow some accounts specialised in this [...] I started to feel new things inside my body [...] When you see the first changes, you start to feel better. It was all very spontaneous. Triana Maida (in OHLALÁ!, La Nación-05.07.2018)

Not only is the spatiality linked to these practices transformed, but the temporality associated with it is also subsidiary to an impulse that seeks to bring a supposedly highly individual time into line with the homogenising and de-personalising tendencies that pervade everyday life. Technology appears here to carry this duality of meaning: it consecrates the grey transformation of vitalities into "zeros and ones", but at the same time it opens up the possibilities for these "searches for the self" where the aim is to "spontaneously express" what happens to my body.

To draw attention to fit-influencers activity, Forbes magazine mentions:

They stand up. They throw themselves. They look good in lycra. And they're making a fortune showing their fans effective workout regimens and healthy lifestyles. (Forbes-10.04.17)

Beyond the process of 'monetarisation', even before the commodification of audience (Fuchs 2014) is established as a privileged global chain of value production in the current mode of global capitalist accumulation, the activity of fit-influencers alerts us to the ways in which the body is socially re-configured to be actionable by the metabolic mechanisms 'demanded' by naturalised, globally expanded 'lifestyles'.

... the body is "armed" with nutrition and deep rest. A stressed body does not recover and I am not only talking about sleep (which always has to be at night!) but also about mental rest. (Musa Argentina, 24 February 2018) 
It is precisely this transformation that raises questions about the possible articulation between the desire to "maintain a fit body", which has become a "lifestyle", and the requirements of the productive processes of the current model of accumulation. In other words, it is worth asking here how a "being-well (for-work/for-life)" assumed as a "philosophy of life" and promoted in social networks, is expressed through the training of the body and emotions, and merges with the metabolic processes "typical" of our social formations.

\section{Fit-influencers and the "home" routine: emotional training gurus}

Now, recovering the approaches made so far, we can establish that the structuring of a productive body has been one of the central concerns of modernity. Thus, the fitinfluencers constitute a paradigmatic experience that highlights the renewed impulse to intervene on bodies from the configuration of time-spaces enabled by the expansion of digital technologies. In this section we would like to focus on the narratives linked to emotionalities, as an element of a particular political economy of morality. That is, on how the meaning of these "trainings" carried out and promoted by social networks, and led by a kind of "training gurus", constitute the expression of a significant set of affectives practices. These practices could be seen as indispensable mechanisms that link productive self-demands with the "homemade" management of passions.

We take up here some experiences recorded from the situated virtual ethnography and the in-depth interviews conducted. To begin with, we focus on Maria's experiences. She was a key actor in our research because she allowed us to characterize the profile of someone who participates in dynamic sectors of the labor market (service sector) and who does not "come from the world of sports". She began to be curious about the activity of running and thus increased her dedication to it. At the same time she becomes an fit-influencers in the terms we have defined here: that is to say, although it does not reach the audience generation or the monetization that is expressed in the fit-influencers on which Forbes magazine focuses its attention, it nevertheless constitutes a reference in local social networks on the subject through publications focused on training, healthy life, etc. Besides, it participates in certain circuits of commercialization, such as brands diffusion, which could be considered as the previous steps to the monetization of the activity in the networks.

The first issue we would like to highlight from Maria's experience is the imperative "do-it-yourself" reason touted by "digital gurus" as a specific component that shapes a moral mandate ("be well") aggiornado to the just-in-time era. In the context of the interview, Maria tells us:

... Running changed me... I always say that it changed me a lot, it showed me a Maria that I didn't know, that I had inside. That I could overcome limits, that I could leave some little things aside, and I take those little moments to go running and clear my head and enjoy it (...) it happened to me in my first marathon last year, in the last $200 \mathrm{~m}$ I was crying, I don't know, I don't know if it's the months I've been training, the times I've said: No, I don't do that because 


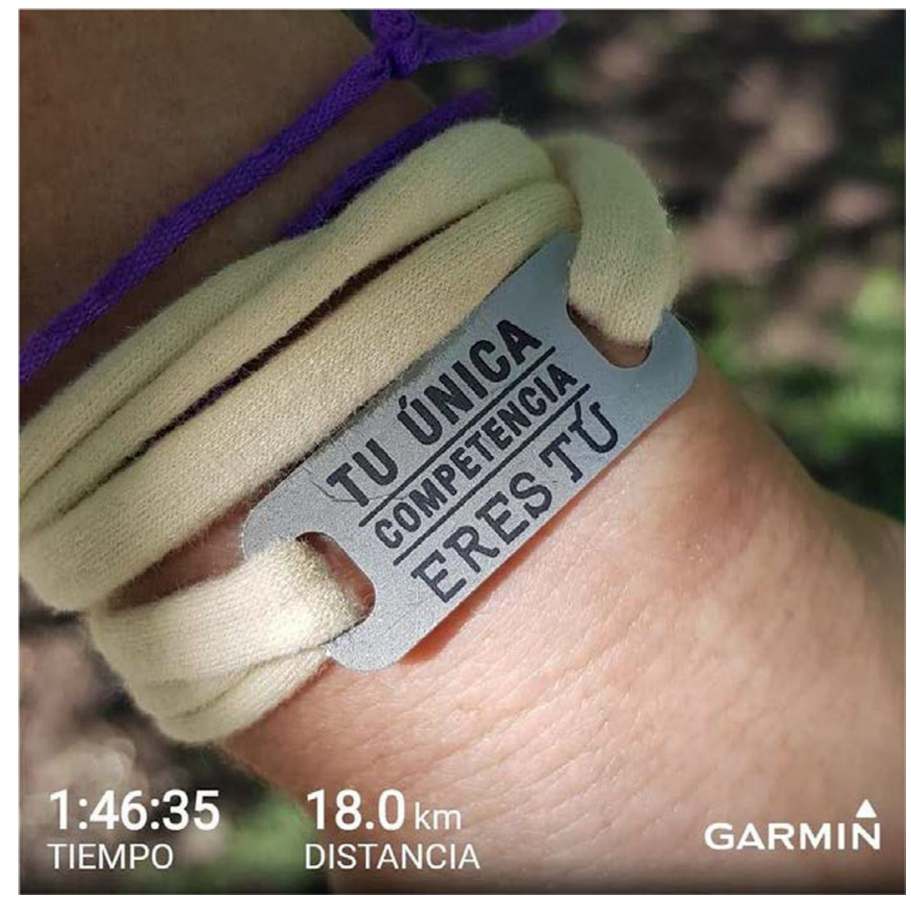

Fig. 1 Your only competition is you. Source: EV Registry-Facebook profile Maria—2018

I have to go running, or I stop doing things because I want to train... And a lady who saw that I was very excited, grabbed my hand, and I continued with them, the three of them. She was with her husband, and the three of us arrived as if we had known each other all our lives (...) A lady who was running with her husband, and saw me and told me not to cry, come on, you are just a little bit away, come on, come on. She gave me her hand, and well, I don't know, it's something, I don't know if I can transmit it with words. (Interview María 2018)

This emotionality, which cannot be put into words in the interview, had been a recurring content in her social media posts: photos of Maria "excited", crying, accompanying messages about self-improvement, acknowledgements and thanks in various situations (mainly races). These elements share protagonism in Maria's "wall" (Facebook) together with another recurrent component: the idea of each race is "against yourself". The photo showing her wristband with the legend: "your only competition is you" (see Fig. 1), together with the times and routes of a practice, emphasize the aforementioned idea, which is representative of many of the messages that are reiterated in the profiles followed.

This element, self-improvement, which may not be novel in what we have defined here as "new body training techniques", acquires a particular meaning when superimposed with digital labour. Thus, the expansion of the message 
"everyone can train" from the phenomenal "massive precision" enabled by the hyperconnectedness of social networks, is related to an equally expanded, shapeless and almost unnoticed mandate: "you cannot stop training your emotions". The practice, the story and the first-person image construct a narrative that enhances the dimensions of a particular experience ("the ways in which I made it") as a kind of self-fulfilling prophecy structured in terms of its emotional effectiveness. Thus, the audience of social networks constitute the followers of that secular religiosity that "has the mandate to get emotionally moved" by this practice because it has naturalized "the faith" that "connects" them, making each communicated experience (each post) to be perceived in line with the lived impressions. Thus, even if someone doesn't train, doesn't run, doesn't know Maria, he/she can equally excite with her posts, with her achievements, and can also make his/her own the "mantras" that derive from "what he/she perceives" as successful, as the desired body shape (even if it doesn't respond to the canons that characterize the activity: because "everyone can run"), as the right way to feel (even if he/she suffers, or feel bad, that "is what's right" because "we can all self-improve").

Another consideration is that the current rhythms linked to the structuring of commodity production chains around the emotional work (Hochschild 1983) involved in the "being-fit-influencer" (i.e., in the objectification and alienation of vital energies through the management of emotions, in this case expressed in the elaboration of publications in social networks), requires a particular naturalized capacity of time-space management derived from the expansion of digital life.

Work as a time-space coordinate is still an important reference for life and, therefore, an unavoidable point of connection between training and work activity. In this regard, Maria tells us:

(running helped me) a little in terms of routine, we could say, in resting, in (doing) things on time, in being orderly. To do this (running) you have to have a more orderly life (...) And also that vitality that it gives you, that thing of being in the face of adversity, let's say, adversity in the sense of the plan, of what you have in front of you every day in training. Yes, yes, I can also feel it in everyday life. At work, in the family, in whatever. So in that, maybe that's what it is: to me it's like it changed me and made me more positive, all of this.

(Interview Maria 2018)

In spite of the "crumbling" with which Castel (1997) announces a certain relaxation of work as an organizer of "daily life", this continues to be for Maria a place centrally crossed by occupational activities. And in this sense-as we have been remarkingtraining does not constitute a different world, but is tuned in as an input for productivity: running serves her to be orderly and to plan. The irruption of the Net, with all the digital supports that become true prostheses of the body, gives complexity to the management of time/space, since these implode in the face of the subjects' capacity to define the situation. Thus, between "work" and "leisure/home" as organizing spaces of modern daily life, the smartphone and the whole series of digital devices that invade everyday life open up diverse temporal-spatial aspects whose reading key can be characterized from the dispositions of the bodies. It is precisely here where we could find 
in the practices we have been focusing on (the fit-influencers), a new twist in the bodytime/space-work relationship.

The routines and "home-made" recipes not only suture the spatio-temporal impediments to training, but also (and centrally) this particular conception of time/space linked to the digital appears again as a moral content: the digital's prevalence comes here as a naturalized condition of the expansion of that "should be". The publication of another local fit-influencers (including Maria's network of relationships) is significant in this direction:

Since I was a kid I understood that I wasn't going to convince everyone, the times on your watch don't tell if you are better or worse than others (EV Record-Instagram profile Marcelo 2018).

It is not only that the "competition is with yourself", but the fact that this is happening in/through social networks also reveals the existence of a series of bodily dispositions that make possible the digitally listen of this message. These dispositions consecrate what this message carries as a practice that delimits and distributes "what is good". In the here/now that the interaction in social networks implies, there are many "others" willing to look from their particular time-spaces and to be moved by the mandate expressed by that "post".

In other times, the reduced world of people who attended the arrival of the marathon participated in a ritual whose affective content was linked to a series of values (suffering to achieve the goal, etc.) that were re-lived in a limited way. On the contrary, nowadays, the possibility of broadcasting live on social networks through a smartphone the arrival of a marathon has the potential to open an extended time-space for the reproduction of the aforementioned moral content. This action has a double value: it is on the one hand massive (because of the capacity to generate large audiences that digital technology allows) but it is also at the same time something specific and individual (because it reaches the personal device of an individual, so that he/she can activate the possibility of getting excited in any of the multiple situations he/she finds, and in very personal connections with his/her biography).

Digital interaction does not take place in a "neutral" social environment, but rather the platform (regardless of the message) unnoticedly imposes the widespread mandate: "if I am not on the networks I do not exist, and I cannot be on the networks without being emotionally moved by these things". What is needed to live the experience linked to these practices, where the fit-influencers play a leading role, is not only the cognitive capacity to de-code the zeros and ones that travel through digital networks, but also the affective ability to be able to be moved by the precise impressions that circulate on the "platforms".

\section{Conclusions: the uberization of training and the renewed spirit of capitalism}

Problematizing the activity of the fit-influencers not only has to do with the structuring of new markets (of audiences to be captured by new marketing strategies, sportswear, etc.), nor with the well-known "unpaid work" that is configured behind 
the expansion of digital labour that this practice entails, but this activity is productive centrally in its relation to the realization of an ideological "surplus-value" (Silva 1970). That is to say, with the profound and often unnoticed consecrating effects of a "only possible world": precisely a world where performing "body and soul" becomes an imperative of a secular religiosity built around the demands of bodily energies available to guarantee the mutations of the geometries of capital. "Assembling the body" and "resting the mind" are the liturgy of a secular practice that is not instantiated in the margins of the (labor) market, but is the foundation of a reterritorialization of productive times.

In this sense, with regard to the "spirit of capitalism", we find relevant the proposal of the sociologists Boltanski and Chiapello (2002) who, based on a recovery of the archaeology of the ethos that gave rise to capitalism according to Weber, recognize three different spirits throughout modern history:(a) that of bourgeois capitalism, where the relationship between owner and proletarian was close as the incipient productive structures were "familiar"; (b) that of large companies, in the framework of which interpersonal relations are "bureaucratized" and the identity elements (the "familiar") of production units disappear; and (c) that of today's "globalized" capitalism, which resorts to new technologies. A spirit characterized by two movements: one endogenous, consisting of the logic of accumulation legitimized by it, and the other exogenous linked to the ideologies it appropriates to offer society that which does not exist: the ethical and rational foundations to summon the dispossessed classes to participate in a process of accumulation that gives them such a character: the "dispossessed being".

It is precisely to this spirit of the times that we attribute the emergence of these new forms of training, as part of a politics of bodies and emotions. This picture is complemented by the aforementioned digital technologies and the way in which it make possible, in our opinion, the structuring of labor and the conflictual processes that go through it. In this regard, Cingolani (2016), argues that the great power of transformation of sociability that these technologies possess lies in the dialectic between "link and outcome". This phenomenon, according to the author, is framed in a global scenario where capitalism has contributed to reorganize the division of labor as never before. In this way, the "disengagements" typical of the "outsourcing" of labor (a product of the increasingly widespread practices of subcontracting or temporary employment), find in the referred digital technology an effective compensation. This process, ultimately, would configure what the aforementioned author designates as a "platform capitalism", that is: the reconfiguration of the system of domination based on a sort of "uberization" of the economy, which translates into a refinement of the rudimentary mechanisms of labor fragmentation and control, and whose resulting models are euphemistically presented through terms such as: "collaborative economy" or "sharing economy".

In this context, if the birth of Western capitalism, as observed by Weber, was marked by the moral mandates associated with (ascetic) Protestantism, and the globalization of capitalism in the twentieth century meant the expansion of the legitimizing ideologies of these new phases, what is presented around the fit-influencers opens questions about the epochal renovations in the political economy of morality, characterized by the emotionalization in/by the digital. These processes-as we 
saw-are structured in a particular tension between the massive and the individual, as well as from a phenomenal capacity to instantiate themselves in the multiple interstices opened by digital times/spaces. In other words, if training and work have thus become two actions in the process of valorization of the body according to the possibilities of production and reproduction of the current order of exploitation, the question about the fit-influencers can refer us to think of it as a metaphor of the mechanisms that are deployed today to connect the renewed uses and expected dispositions of the "body-in-form/productive" with the "feeling fit" as a "lifestyle" that expresses an identity in accordance with the current regimes of sensibilities.

Funding The reflections and data presented in this paper have been produced within the framework of a line of research in which collective and individual projects converge. The institutions that support and/or finance these projects are: the Universidad Nacional de Villa María ("Sensibilidades sociales, educación virtual y trabajo digital: Entrenar emociones en/por Internet. Villa María 2020-2022"; "Emotional work and training. Villa María, 2018-2019"; "Body, work and body energies. New body training techniques and the transformations of the transformations of the world of work from the experience of the subjects. Villa María, 2016-2018"), National Scientific and Technical Research Council ("Social sensibilities and digital work. Conflictivities emerging in the context of the new morphologies of work 2020-2022"), and the Research Centre on Consumption, Sensibilities and Creativity, University of Palermo.

\section{References}

Abidin C (2016) Visibility labour: engaging with influencers' fashion brands and \#OOTD advertorial campaigns on Instagram. Media Int Aust 161(1):86-100. https://doi.org/10.1177/1329878X16 665177

Alasuutari P (1997) The discursive construction of personality. In: Lieblich A, Josselson R (eds) Narrative study of lives, vol 5. Sage, Thousand Oaks, pp 1-20

Antunes R (2005) Os sentidos do trabalho: ensaio sobre a afirmacao e a negacao do trabalho. Boitempo, San Pablo

Boltanski L, Chiapello E (2002) El nuevo espíritu del capitalismo. Ediciones Akal, Madrid

Castel R (1997) La metamorfosis de la cuestión social: una crónica del asalariado. Paidós, Buenos Aires

Cigaina A, Pascual AM (2020) Cuerpos e Imágenes en Instagram: el fenómeno de las fitfluencers y el cuerpo fit. In: XXXIII Jornadas de Investigacion y XV Encuentro Regional SI + Imágenes

Cingolani P (2016) Capitalismo de plataforma: nuevas tecnologías de la comunicación e internacionalización del trabajo. Boletín Onteaiken, 22 (11):42-47

De Sena A, Lisdero P (2014) Etnografía Virtual: aportes para su discusión y diseño. In: De Sena A (ed) Caminos cualitativos: aportes para la investigación en Ciencias Sociales. CICCUS, Buenos Aires, pp 71-100

Fernandez Lerma A (2017) Estudio del origen de la figura del influencer y análisis de su poder de influencia en base a sus comunidades. http://hdl.handle.net/10230/36313

Fuchs C (2014) Digital Labour and Karl Marx. Routledge, New York

Giddens A (2003) La Constitución de la Sociedad. Amorrortu, Buenos Aires

Goldie P (2003) Narrative, emotion, and perspective. In: Kieran M, Lopes DM (eds) Imagination, philosophy, and the arts. Routledge, London, pp 55-69

Gomez Coelho OB, Cipiniuk A (2019) Quem influencia as influenciadoras digitais? Comunicação, tendência e moda no Instagram. ModaPalavra 12(24):7-22. https://doi.org/10.5965/1982615x12 242019007

Gomez Nieto B (2018) El influencer: herramienta clave en el contexto digital de la publicidad engañosa. Methaodos Revista de Ciencias Sociales 6:149-156. https://doi.org/10.17502/m.rcs.v6i1.212

Gonzalez-Carrion EL, Aguaded I (2019) Los instagrammers más influyentes de Ecuador. Universitas, Revista de Ciencias Sociales y Humanas, Universidad Politécnica Salesiana 31:159-174. https://doi. org/10.17163/uni.n31.2019.08 
Gubrium JF, Holstein JA (2008) Narrative ethnography. In: Hesse-Biber SN, Leavy P (eds) Handbook of emergent methods. The Guilford Press, New York and London, pp 241-264

Guiñez-Cabrera N, Mansilla-Obando K, Jeldes-Delgado F (2020) La transparencia publicitaria en los influencers de las redes sociales. Retos Revista de Ciencias de la Administración y Economía 10(20):265-281. https://doi.org/10.17163/ret.n20.2020.05

Habermas T (2019) Emotion and narrative: perspectives in autobiographical storytelling. Cambridge University Press, Cambridge

Hijós N (2018) Influencers, mujeres y running: algunas consideraciones para entender los nuevos consumos deportivos y los estilos de vida saludable. Lúdica. https://doi.org/10.17227/ludica.num27-9442

Hochschild AR (1983) The managed heart: commercialization of human feeling. In: O’Brien J (ed) The production of reality: essays and readings on social interaction. Sage, Thousand Oaks, pp 320-336

Khamis S, Ang L, Welling R (2017) Self-branding, "micro-celebrity" and the rise of social media influencers. Celebr Stud J 8(2):191-208. https://doi.org/10.1080/19392397.2016.1218292

Lisdero P, Marengo L (2010) Neo-colonialismo y nueva morfología del trabajo en la Argentina post 2001. El conflicto social en los Call Center y las Empresas Recuperadas. In: Scribano A, Boito E (ed) El purgatorio que no fue. Acciones profanas entre la esperanza y la soportabilidad. CICCUS, Buenos Aires, pp 155-177

Lisdero P, Brandan M, Pellón I, Dubois D (2017) Entrenando sensibilidades: reflexiones metodológicas en torno al trabajo y las "nuevas formas de entrenamientos. In: Gandía C, Vergara G, Lisdero P, Quattrini D, Cena R (eds) Metodología de la investigación: estrategias de indagación, I. ESE: Estudios Sociológicos Editora, Buenos Aires, pp 87-104

Marwick A (2015) Instafame: Luxury Selfies in the Attention Economy. Public Culture 27(175):137160. https://doi.org/10.1215/08992363-2798379

Mauss M (1979) Sociología y antropología. Tecnos, Madrid

Melucci A (1977) Il corpo ignoto. L. Ambrosi, L’enegia dell'umano. Feltrinelli Economica, Milán

Noonan M (2018) Social media fitness influencers: innovators and motivators. University of Iowa, Iowa City

Pinheiro Koury MG (2019) Prologue: emotions, labour and society 4.0. In: Scribano A, Lisdero P (eds) Digital labour, society and politics of sensibilities. Palgrave Macmillan, London

Ramirez Villanueva A (2018) Estudio sobre la personalidad de los influencers en Instagram. Universidad Autónoma de Barcelona, España. https://ddd.uab.cat/record/195884

Rodriguez PE (2015) Espetáculo do dividual: tecnologías do eu e vigilância distribuída nas redes sociais. Revista Eco Pos, Tecnopoliticas e Vigilancia 2(18):57-68

Schouten AP, Janssen L, Verspaget M (2020) Celebrity vs Influencer endorsements in advertising: the role of identification, credibility, and product-endorser fit. Int J Advert 39(2):258-281

Scribano A (2015) ¡Disfrútalo! Una aproximación a la economía política de la moral desde el consumo. Elalephcom, Ciudad Autónoma de Buenos Aires

Scribano A (2017) Normalization, enjoyment and bodies/emotions: Argentine sensibilities. Nova Science Publishers, New York

Scribano A (2018) Politics and emotions. Studium Press, Houston

Scribano A (2021) Colonization of the inner planet: 21st century social theory from the politics of sensibilities. Routledge, New York

Scribano A, Lisdero P (2019) Work and sensibilities: commodification and processes of expropiation around digital labour. In: Scribano A, Lisdero P (eds) Digital labour, society and politics of sensibilities. Palgrave Macmillan, London

Silva L ([1970]2017) La plusvalía ideológica. Fundación para la cultura y las Artes, Caracas

Simó Quiles A (2018) Investigación del papel de dos deportistas famosos, como influencers, en la red social Instagram. Universidad Politécnica de Valencia, Valencia. http://hdl.handle.net/10251/114863

Torres-Romay E, Garcia Miron S (2020) Influencers y coronavirus. Los contenidos sobre la pandemia COVID-19 en las publicaciones de prescriptores de redes sociales en España (2020): el caso de Instagram. Quaderns del CAC 46:81-91

van den Ecker M, Sevignani S (2020) Media and communication in digital capitalism: critical perspectives. Global dialogue. Mag Int Sociol Assoc 10(3):20-22 